Jurnal Pemikiran \& Penelitian Psikologi

\title{
PSIKOLOGIA
}

p-ISSN: $185-0327$

e-ISSN: 2549-2136

www.jurnal.usu.ac.id/psikologia

\section{HUBUNGAN ANTARA KONSEP DIRI DENGAN PENYESUAIAN DIRI PADA PECANDU NARKOBA DI PANTI REHABILITASI SIBOLANGIT CENTER}

\section{THE RELATIONSHIP BETWEEN SELF-CONCEPT AND THE SELF- ADJUSTMENT OF DRUG ADDICTS IN THE SIBOLANGIT REHABILITATION CENTER}

\author{
Yoseva Okta Marini Naibaho dan Rahma Fauzia Sinulingga \\ Psikologia: Jurnal Pemikiran \& Penelitian Psikologi \\ Tahun 2018, Vol. 13, No. 3, hal.132-141
}

Artikel ini dapat diakses dan diunduh pada:

www.jurnal.usu.ac.id/psikologia

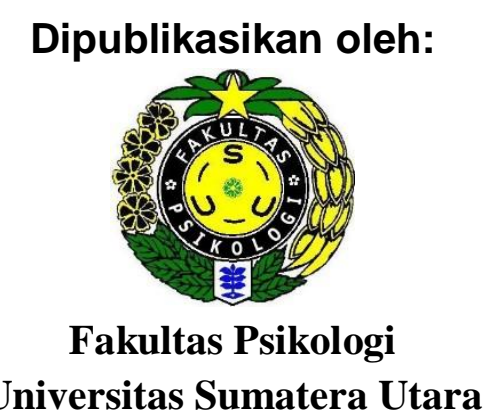

Jl. Dr. Mansyur No. 7 Medan. Telp/fax: 061-8220122

Email: psikologia@usu.ac.id 


\title{
HUBUNGAN ANTARA KONSEP DIRI DENGAN PENYESUAIAN DIRI PADA PECANDU NARKOBA DI PANTI REHABILITASI SIBOLANGIT CENTER
}

\author{
Yoseva Okta Marini Naibaho dan Rahma Fauzia Sinulingga \\ Universitas Sumatera Utara
}

\begin{abstract}
ABSTRAK
Penelitian ini merupakan penelitian yang bersifat korelasional yang bertujuan untuk mengetahui hubungan antara konsep diri dengan penyesuaian diri pecandu narkoba di panti rehabilitasi. Metode pengambilan data yang digunakan adalah teknik simple random sampling dengan jumlah subjek penelitian sebanyak 30 orang pecandu narkoba. Data penelitian ini diungkap dari skalakonsep diri yang disusun berdasarkan teori Calhoun \& Acocella $\left(\mathrm{rxx}^{\prime}=0,821\right)$ dan skala penyesuaian diri yang disusun berdasarkan teori Schneiders $\left(\mathrm{rxx}^{\prime}=0,847\right)$. Teknik analisa data yang digunakan adalah korelasi Pearson Product Moment. Hasil analisis data menunjukkan bahwa ada hubungan positif antara konsep diri dengan penyesuaian diri pada pecandu narkoba di panti rehabilitasi dengan nilai $\mathrm{p}=$ $0,003(\mathrm{p}<0,05)$ dan koefisien korelasi sebesar rxy $=0,494$. Artinya semakin positif konsep diri, maka penyesuaian diri yang dilakukan akan semakin baik.
\end{abstract}

Kata kunci : konsep diri, penyesuaian diri, pecandu narkoba

\section{THE RELATIONSHIP BETWEEN SELF-CONCEPT AND THE SELF- ADJUSTMENT OF DRUG ADDICTS IN THE SIBOLANGIT REHABILITATION CENTER}

\begin{abstract}
S
This study is a correlational study that aims to determine the relationship between self-concept and selfadjustment of drug addicts in rehabilitation institutions. The used data collection method was simple random sampling technique with the number of research subjects as many as 30 drug addicts. The data of this study are revealed from the self-concept scala based on the theory of Calhoun \& Acocella (rxx '= 0.821 ) and the adjustment scale which is compiled based on Schneiders' theory ( $\mathrm{xxx}^{\prime}=0.847$ ). Data analysis technique used is Pearson Product Moment correlation. The results of data analysis showed that there was a positive relationship between self-concept and self-adjustment in drug addicts in rehabilitation institutions with a value of $p=0,003(p<0.05)$ and a correlation coefficient of rxy $=0.494$. This means that the more positive the self-concept is, the better the self-adjustment will be.
\end{abstract}

Keywords : self-concept, self-adjustment, drug addicts.

*Korespondensi mengenai penelitian ini dapat dilayangkan kepada: psikologia@usu..ac.id
Rekomendasi mensitasi:

Naibaho, Y.O., Sinulingga, R.F. (2018). Hubungan antara Konsep Diri dengan Penyesuaian Diri pada Pecandu Narkoba di Panti Rehabilitasi Sibolangit Center. Psikologia :Jurnal Pemikiran dan Penelitian Psikologi, 13(3), 132-141 
Rehabilitasi memberikan peran terpenting dalam pembinaan bagi pecandu narkoba. Sesuai dengan Pasal 35 tahun 2009 tentang narkotika dijelaskan bahwa, rehabilitasi adalah proses kegiatan penyembuhan terpadu secara fisik, mental, dan sosial untuk membebaskan para pecandu dari ketergantungan narkoba. Masuknya pecandu narkoba ke panti rehabilitasi menghadapkan pecandu narkoba pada berbagai tuntutan seperti tuntutan tanggung jawab, tuntutan kemandirian.

Tuntutan tanggung jawab adalah tuntuntan terhadap residen untuk mematuhi peraturan panti rehabilitasi, mengikuti program-program yang telah ditetapkan, dan menjalankan setiap tugas dengan tanggung jawab. Tuntutan kemandirian terlihat dari ketentuan yang mengharuskan residen untuk mengurus sendiri kebutuhan pribadinya seperti merapikan tempat tidur, membersihkan kamar. Tuntutan-tuntutan yang ada di panti rehabilitasi dapat menimbulkan stres.

Untuk meminimalisir stres dan dampak negatif yang mungkin ditimbulkan, maka diperlukan penyesuaian diri sebagai mekanisme yang efektif untuk mengatasi stres dan menghindarkan terjadinya krisis psikologis (Calhoun \& Acocella,1990). Penyesuaian diri merupakan suatu proses yang mencakup respon-respon mental dan tingkah laku, yang merupakan usaha individu agar berhasil mengatasi kebutuhan, ketegangan, konflik, dan frustasi yang dialami didalam dirinya (Schneider dalam Agustiani, 2009).

Penyesuaian diri dipengaruhi oleh berbagai faktor. Schneider (1964) menyebutkan bahwa kondisi psikologis merupakan salah satu faktor yang mempengaruhi penyesuaian diri. Kondisi psikologi meliputi keadaan mental individu yang sehat. Individu yang memiliki mental yang sehat memiliki kemampuan untuk melakukan pengaturan terhadap dirinya sendiri dalam membentuk perilakunya secara efektif.

Biasanya individu yang sedang melakukan penyesuaian diri dipengaruhi oleh pandangan dirinya terhadap dirinya sendiri yang biasa di sebut dengan konsep diri. Konsep diri mempunyai pengaruh yang cukup besar terhadap perilaku individu, yaitu individu akan bertingkah laku sesuai dengan konsep diri yang dimiliki Calhoun \& Acocella (1990). Label yang diberikan pada sebagai pecandu narkoba dapat dipersepsi negatif atau positif oleh individu yang bersangkutan. Label yang dipersepsi negatif membuat individu menjadi terbebani, hal tersebut cenderung akan membawa efek negatif terhadap perkembangan sisi psikologisnya.Individu akan merasa gagal dan terbuang ketika tidak dapat memenuhi tuntutan lingkungan, serta menjadi tidak percaya diri, merasa tidak berharga, dan rendah diri. Kondisi ini diperburuk dengan adanya fenomena di masyarakat yang memandang negatif pecandu narkoba.

Konsep diri bukanlah hal yang dibawa sejak lahir, melainkan berdasarkan pengalaman. Setiap pengalaman menyenangkan maupun tidak menyenangkan yang dialamioleh individu akan menjadi bagian terpenting dalam kehidupannya. Pengalaman-pengalaman tersebut dapat mempengaruhi cara individu dalam memandang dirinya sendiri dan 
dapat membentuk sebuah penilaian terhadap dirinya.

Fitts mengatakan bahwa konsep diri merupakan aspek penting dalam diri seseorang, karena konsep diri seseorang merupakan kerangka acuan (frame of reference) dalam ia berinteraksi dengan lingkungannya. Fitts juga mengatakan bahwa konsep diri mempunyai pengaruh yang kuat terhadap tingkah laku seseorang. Oleh karena itu, dengan mengetahui konsep diri seseorang maka akan lebih memudahkan untuk meramalkan dan memahami tingkah lakunya.

Hal yang serupa dikemukakan oleh Calhoun \& Acocella (1990) yang menyatakan bahwa konsep diri merupakan bagian diri yang mempengaruhi setiap aspek pengalaman, baik itu pikiran, perasaan, persepsi dan tingkah laku individu yang terdiri dari pengetahuan, pengharapan dan penilaian terhadap diri sendiri. Sejalan dengan itu, Rogers (dalam Mischel, Shoda, \& Smith, 2004),mengemukakan bahwa konsep diri itu mempengaruhi persepsi dan perilaku seseorang.

Pecandu yang memiliki konsep diri positif akan tampil lebih percaya diri dalam menghadapi berbagai situasi. Sebaliknya pecandu yang mengembangkan konsep diri negatif, mempunyai kesulitan dalam menerima dirinya sendiri, sering menolak dirinya serta sulit bagi mereka untukmelakukan penyesuaian diri yang baik.Melalui konsep diri yang positif akanmembantu pecandu dalam menyelesaikan masalah yang dihadapi dan sebaliknya pecandu yang mempunyai konsep diri yang negatif akan kesulitan dalam menyelesaikan masalahnya (Montana, 2001). Konsep diri merupakan hal penting karena dengan konsep diri akanmembantu individu untuk mengenali dirinya baik itu dari sisi positif dan negatif, serta apa yang boleh dan tidak boleh dilakukannya.

Purtosuwido (1993) mengatakan bahwa individu yang memiliki konsep diri tinggi lebih mampu untuk menyesuaikan diri, dimana individu dapat menempatkan dirinya dalam masyarakat maka individu itu akan diterima dengan baik oleh masyarakat, begitu juga sebaliknya. Hasil penelitian ini juga sejalan dengan penelitian dilakukan oleh Habibullahi (2010) dengan hasil ada hubungan positif antara konsep diri dengan penyesuaian diri.Individu yang memiliki konsep diri yang negatif, maka tingkat penyesuaiannya buruk, berbeda jika individu memiliki konsep diri positif, maka semakin baik penyesuaian dirinya. Pada diri seorang konsep diri yang positif berarti individu mempunyai penerimaan terhadap lingkungan sosialnya. Individu yang memiliki konsep diri positif maka memiliki perilaku yang positif pula. Sehingga individu tersebut mendapatkan umpan balik yang positif dalam lingkungannya.

Dari uraian di atas dapat dinyatakan bahwa konsep diri dapat dijadikan acuan untuk melihat kemampuan penyesuaian diri pengguna narkoba. Apabila konsep diri seseorang positif maka semakin baik penyesuaian dirinya, sebaliknya jika konsep diri seseorang negatif maka semakin tidak baik penyesuaian dirinya, karena konsep diri merupakan gambaran dari kepribadian seseorang sehingga sangat berpengaruh dalam menentukan kemampuan penyesuaian diri.

\section{Konsep Diri}


Konsep diri merupakan pandangan atau gambaran mental yang dimiliki oleh individu mengenai dirinya yang berisi tentang pengetahuan mengenai dirinya, pengharapan yang ingin dicapai di masa yang akan datang, serta kemampuan individu dalam menilai dirinya sendiri baik secara fisik, sosial, maupun psikologis yang dibentuk melalui pengalaman-pengalaman atau hasil belajar dari interaksi individu tersebut dengan lingkungannya.

Konsep diri diukur dengan menggunakan skala yang disusun berdasarkan dimensi-dimensi konsep diri yang diungkapkan oleh Calhoun \& Acocella (1990) yaitu: pengetahuan, harapan, dan penilaian. Semakin tinggi skor konsep diri, semakin positif konsep diri dan sebaliknya semakin rendah skor konsep diri, semakin negatif konsep diri.

\section{Penyesuaian Diri}

Penyesuaian diri adalah kemampuan subjek dalam memberikan berbagai respon, baik respon mental maupun respon tingkah laku yang berkaitan dengan emosionalitas, mekanisme pertahanan diri, perasaan frustasi personal, pertimbangan rasional dan pengarahan diri, kemampuan belajar, pemanfaatan pengalaman masa lalu, serta sikap-sikap yang realistis dan objektif untuk mencapai keselarasan antara tuntutan dari dalam diri dengan tuntutan dari lingkungan. Penyesuaian diri dalam penelitian ini diungkap melalui skala penyesuaian diri yang disusun oleh peneliti berdasarkan teori penyesuaian diri yang dikemukakan oleh Schneider (1964) yang mengungkap karakteristik penyesuaian diri yang baik yaitu: tidak terdapat emosionalitas yang berlebih, tidak terdapat mekanisme psikologis, tidak terdapat perasaan frustrasi personal, kemampuan untuk belajar, pemanfaatan pengalaman masa lalu, sikap realistik dan objektif, pertimbangan rasional dan pengarahkan diri. Skala ini menunjukkan semakin tinggi total skor yang diperoleh individu maka akan menunjukkan penyesuaian diri yang baik, sebaliknya semakin rendah total skor yang diperoleh individu maka akan menunjukkan penyesuaian diri yang buruk.

\section{HIPOTESIS PENELITIAN}

Hipotesa dalam penelitian ini adalah: ada hubungan yang positif antara konsep diri dengan penyesuaian diri pada pecandu narkoba di Panti Rehabilitasi Sibolangit Center. Artinya semakin positif konsep diri pada pecandu narkoba, maka penyesuaian diri pada pecandu narkoba juga akan semakin baik, demikian sebaliknya semakin negatif konsep diri, maka penyesuaian diri pada pecandu narkoba yang sedang rehabilitasi juga akan semakin buruk.

\section{METODE Variabel Penelitian}

Variabel-variabel yang digunakan dalam penelitian ini adalah:

$$
\begin{array}{ll}
\mathrm{X}_{1} & \text { : Konsep diri } \\
\mathrm{X}_{2} & \text { : Penyesuaian diri }
\end{array}
$$

\section{Partisipan}

Jumlah total subyek yang diambil untuk penelitian ini sebanyak 30 orang pecandu narkoba yang direhabilitasi di Panti Rehabilitasi Sibolangit Center.

\section{Alat Ukur}

Pada penelitian ini, pengumpulan data dilakukan dengan menggunakan skala. Terdapat 2 (dua) skala yang digunakan yaitu skala konsep diri dan skala penyesuaian diri. Aitem terdiri dari pernyataan dengan lima pilihan jawaban yaitu : SS (Sangat Sesuai), S (Sesuai), N (Netral), TS (Tidak Sesuai), dan STS (Sangat Tidak Sesuai).

Uji Realibilitas dan Uji Daya Diskriminasi Aitem 
1. Skala 1 - konsep diri

Jumlah aitem yang diujicobakan sebanyak 15 aitem dan terdapat 6 aitem yang memenuhi indeks diskriminasi $r_{\text {ix }} \geq$ 0,3. Azwar (2007) menyatakan bahwa kriteria berdasarkan korelasi aitem total biasanya digunakan batasan $r_{\text {ix }} \geq 0,3$. Semua aitem yang mencapai korelasi minimal 0,3 daya bedanya dianggap memuaskan. Jumlah aitem yang dipakai adalah sebanyak 9. Aitem-aitem yang memiliki daya beda tinggi bergerak dari $r_{\text {ix }}=0,396$ sampai dengan $r_{\text {ix }}=0,758$. Uji reliabilitas dilakukan terhadap 9 aitem tersebut. Hasil uji coba reliabilitas skala konsep diri dalah sebesar 0,821. Aitem-aitem yang memenuhi kriteria tersebut disusun kembali menjadi susunan skala yang digunakan dalam pengambilan data yang sebenarnya

2. Skala 2 - Penyesuaian Diri

Jumlah aitem yang diujicobakan sebanyak 35 aitem dan terdapat 21 aitem yang memenuhi indeks diskriminasi $r_{\text {ix }} \geq$ 0,3. Azwar (2007) menyatakan bahwa kriteria berdasarkan korelasi aitem total biasanya digunakan batasan $r_{i x} \geq 0,3$. Semua aitem yang mencapai korelasi minimal 0,3 daya bedanya dianggap memuaskan. Jumlah aitem yang dipakai adalah sebanyak 14. Aitem-aitem yang memiliki daya beda tinggi bergerak dari $r_{i x}=0,353$ sampai dengan $r_{i x}=0,774$.

Uji reliabilitas dilakukan terhadap 14 aitem tersebut. Hasil uji coba reliabilitas skala konsep diri dalah sebesar 0,847. Aitem-aitem yang memenuhi kriteria tersebut di susun kembali menjadi susunan skala yang digunakan dalam pengambilan data yang sebenarnya.

\section{Teknik Analisa Data}

Metode yang digunakan untuk menganalisa data penelitian ini adalah analisis statistic. Penelitian ini dilakukan untuk melihat hubungan antara konsep diri dengan penyesuaian diri, maka analisa data yang digunakan adalah korelasi Pearson Product Moment.

\section{Uji Normalitas}

$\begin{array}{crr}\text { Uji } & \text { normalitas } & \text { sebaran } \\ \text { menggunakan } & \text { analisis } & \text { statistik }\end{array}$

Kolmogorov-Smirnov. Data dikatakan terdistribusi normal jika harga $\mathrm{p}>0.05$. Hasil uji normalitas dengan menggunakan Kolmogorov-Smirnov adalah sebagai berikut :

Tabel 1. Uji Normalitas

\begin{tabular}{cc}
\hline Variabel & Asymp.Sig \\
\hline $\begin{array}{c}\text { Konsep Diri } \\
\text { Penyesuaian } \\
\text { Diri }\end{array}$ & 0.092 \\
& 0.654
\end{tabular}

Berdasarkan tabel 4, diketahui bahwa uji normalitas pada variabel konsep diri menunjukkan nilai $\mathrm{p}=0.092$ atau $\mathrm{p}>0.05$, maka diketahui bahwa data konsep diri pada 30 orang responden adalah normal, atau memenuhi persyaratan uji normalitas. Pada variabel penyesuaian diri menunjukkan nilai $\mathrm{p}=0.654$ atau $\mathrm{p}>0.05$, maka diketahui bahwa data penyesuaian diri pada 30 orang responden adalah normal, atau memenuhi kaidah persyaratan uji normalitas.

\section{Uji Linearitas}

Uji linearitas dilakukan dengan menggunakan test for linearity, yang menunjukkan bahwa data variabel dukungan sosial keluarga berkorelasi secara linear terhadap self regulated learning. Data penelitian dikatakan berkorelasi secara linear apabila $\mathrm{p}<0.05$ untuk linearity dan nilai Sig pada Deviation From Linearity nilainya $>0,05$. 
Hasil uji linearitas dapat dilihat pada tabel berikut :

Tabel 2. Uji Linearitas

\begin{tabular}{ccc}
\hline Variabel & Linearity & Kesimpulan \\
\hline Konsep Diri & 0.010 & Hubungan Linear \\
$\begin{array}{c}\text { Penyesuaian } \\
\text { Diri }\end{array}$ & 0.010 & Hubungan Linear \\
\hline
\end{tabular}

Berdasarkan tabel diatas, diperoleh

nilai linearity 0.010 untuk variabel konsep diri dan penyesuaian diri. Hal ini menunjukkan bahwa nilai linearity dibawah 0.05 sehingga telah memenuhi asumsi linearitas.

\section{HASIL \\ Korelasi Antar Variabel}

Berdasarkan hasil uji korelasi Pearson Product Moment, nilai korelasi sebesar 0.494 yang berarti bahwa hipotesis diterima.

Tabel 3. Korelasi antara Konsep Diri dengan Penyesuaian Diri

\begin{tabular}{lllll}
\hline Variabel & N & $\begin{array}{l}\text { Korelasi } \\
\text { Pearson }\end{array}$ & Sig,(p) & Keterangan \\
\hline Korelasi & 3 & 0.494 & 0.003 & $\begin{array}{l}\text { Hipotesis } \\
\text { diterima }\end{array}$ \\
$\begin{array}{l}\text { antara } \\
\text { konsep diri }\end{array}$ & & & & \\
$\begin{array}{l}\text { dengan } \\
\text { penyesuaian } \\
\text { diri }\end{array}$ & & & & \\
\hline
\end{tabular}

\section{Kategorisasi Data}

Subjek akan digolongkan ke dalam 2 kategori yaitu tinggi dan rendah. Kategorisasi konsep diri dilakukan dengan menggunakan batas kisaran skor atau fluktuasi skor mean dimana ketika peneliti ingin membuat kategorisasi menjadi dua bagian, sebaiknya dapat dilakukan dengan menggunakan batas kisaran skor atau fluktuasi skor mean (Azwar, 2010).

Pengelompokan konsep diri pecandu narkoba dilakukan dengan pengkategorian subjek berdasarkan kategorisasi skor konsep diri sebagaimana yang tertera pada Grafik1 berikut:

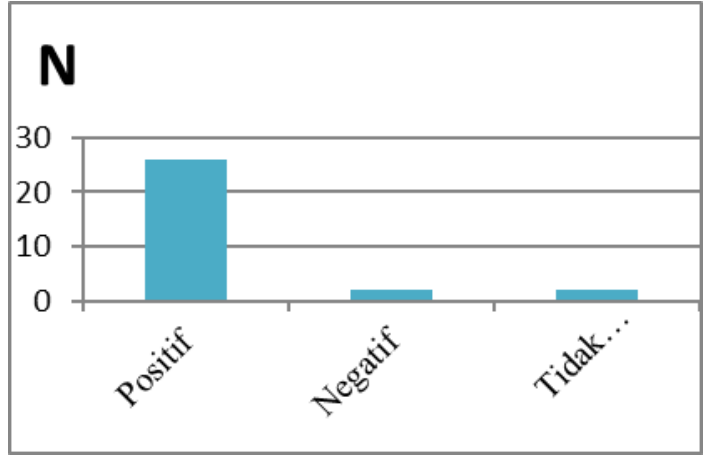

Berdasarkan Grafik 1 diatas, individu yang memperoleh skor 29 keatas dapat disebut memiliki konsep diri yangpositif atau tinggi, sedangkan individu yang memperoleh skor 25 kebawah dapat dikatakan memiliki konsep diri yangnegatif atau buruk. Dari hasil tersebut diperoleh sebanyak $26 \quad(86,66 \%)$ orang masuk ke dalam kategori konsep diri positif dan $2(6,67 \%)$ orang ke dalam kategori konsep diri negatif, sedangkan 2 orang $(6,67 \%)$ tidak diklasifikasikan karena tujuan peneliti hanya memisahkan subjek ke dalam dua kategori yaitu positif dan negatif.

Pengelompokan penyesuaian diri pecandu narkoba dilakukan dengan pengkategorian subjek berdasarkan kategorisasi skor penyesuaian diri sebagaimana yang tertera pada Grafik 2 berikut:

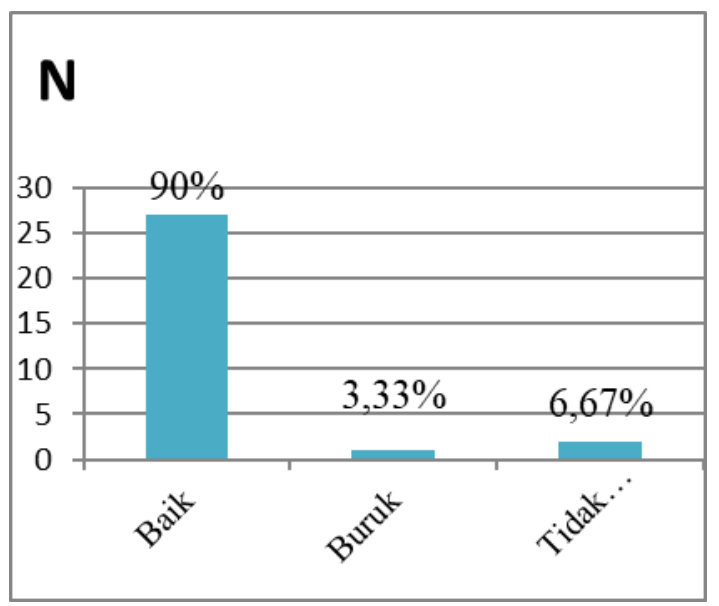

Berdasarkan Grafik 2 diatas, individu yang memperoleh skor 44 keatas dapat disebut memiliki penyesuaian diri yangbaik atau tinggi, sedangkan individu yang memperoleh skor 40 kebawah dapat dikatakan memiliki penyesuaian diri yangburuk atau rendah. Dari hasil tersebut diperoleh sebanyak 27 (90\%) orang masuk ke 
dalam kategori penyesuaian diri yang baik dan $1(3,33 \%)$ orang ke dalam kategori penyesuaian diri yang buruk, sedangkan 2 orang $(6,67 \%)$ tidak diklasifikasikan karena tujuan peneliti hanya memisahkan subjek ke dalam dua kategori yaitu baik dan buruk

\section{DISKUSI}

Tujuan dari penelitian ini adalah ingin melihat hubungan konsep diri dengan penyesuaian diri pada pecandu narkoba di Panti Rehabilitasi Sibolangit Center. Hipotesis penelitian ini adalah ada hubungan yang positif antara konsep diri dengan penyesuaian diri pada pecandu narkoba. Hasil penelitian ini diperoleh nilai $r_{x}=0,494$ dengan signifikansi $\mathrm{p}<0,05$ memperlihatkan bahwa hipotesis penelitian diterima, yaitu ada hubungan positif yang signifikan antara konsep diri dengan penyesuaian diri pada pecandu narkoba di Panti Rehabilitasi Sibolangit Center, yang artinya semakin positif konsep diri pada pecandu narkoba, maka penyesuaian diri pada pecandu narkoba juga akan semakin baik. Kriteria korelasi sebesar 0,494 menurut Sugiyono (2009) termasuk dalam kategori korelasi yang sedang.

Berdasarkan hasil perbandingan antara skor mean empirik dan skor mean hipotetik untuk skala konsep diri menunjukkan bahwa mean empirik lebih besar dari mean hipotetik $(34,53>27)$ yang menjelaskan bahwa konsep diricenderung lebih tinggi dari rata-rata konsep diri populasi yang diasumsikan berdasarkan skala konsep diri. Begitu juga dengan hasil perbandingan antara skor mean empirik penyesuaian diri dengan mean hipotetiknya menunjukkan bahwa mean empirik lebih besar dari mean hipotetik $(51,90>42)$. Hal ini berarti bahwa secara umum penyesuaian diri pecandu narkoba yang sedang menjalani rehabilitasi yang diteliti lebih tinggi dibandingkan dengan populasi yang diasumsikan.
Dalam penelitian ini, jumlah subjek ada sebanyak 30 subjek. Berdasarkan kategorisasi, 26 orang $(86,66 \%)$ termasuk dalam kategori konsep diri positif, dan 2 orang $(6,67 \%)$ memiliki konsep diri yang negatif. Dapat disimpulkan, bahwa bahwa konsep diri data penelitian berada pada kategori positif $(86,66 \%)$. Berdasarkan data penelitian, pecandu narkoba yang sedang menjalani rehabilitasi memiliki konsep diri yang positif, di mana Calhoun \& Acocella (1990) mengatakan bahwa individu yang memiliki konsep diri yang positif individu yang mengenal dirinya dengan baik, dapat memahami dan menerima sejumlah fakta yang bermacam-macam tentang dirinya sendiri, evaluasi terhadap dirinya sendiri menjadi positif dan dapat menerima keberadaan orang lain. Individu yang memiliki konsep diri yang positif akan merancang tujuan-tujuan yang sesuai dengan realitas, yaitu tujuan yang mempunyai kemungkinan besar untuk dicapai, mampu menghadapi kehidupan di depannya serta menganggap bahwa hidup adalah suatu proses penemuan.

Sementara berdasarkan teori dikatakan bahwa individu yang menjadi pecandu biasanya memiliki konsep diri yang negatif dan harga diri yang rendah (Jenny, 2008). Joewana (dalam Gordon 2002) juga mengatakan bahwa pecandu mempunyai konsep diri yangrendah. Pada umumnya, hal ini disebabkan karena pecandu narkoba mendapatkan stigma yang negatif dari masyarakat. Masyarakat memandang perilaku tersebut sebagai tindakan yang negatif, sehingga pecandu narkoba yang terjebak pada perilaku tersebut akan mengalami gangguan pada konsep dirinyasehingga dibutuhkan perbaikan kembali konsep diri untuk menjadi lebih positif lagi.

Selama berada di panti rehabilitasi, subjek penelitian memiliki konsep diri yang postif hal ini bisa disebabkan karena di lingkungan itu subjek mendapatkan penilaian positif dari orang-orang di sekitarnya. Interaksi dari masing-masing residen di mana mereka saling mendukung dan terlibat dalam program 
yang dapat mempengaruhi konsep dirinya masing-masing. Selain itu juga bisa disebabkan lingkungan sekitarnya yang mendukung dan memotivasi mereka. Hal ini sesuai dengan yang dikemukakan Mead (dalam Calhoun \& Acocella, 1990) yang menjelaskan bahwa konsep diriberkembang dalam dua tahap: pertama, melalui internalisasi sikap orang lainterhadap kita; kedua melalui internalisasi norma masyarakat. Dengan kata lainkonsep diri merupakan hasil belajar melalui hubungan individu dengan orang lain. Selain itu, hal ini juga sesuai dengan yang dikemukakan oleh Papalia \& Olds (2007) yang menyatakan bahwa pemberian sosial support dari orang yang berarti di seputar kehidupan individu memberi kontribusi yang terbesar dalam meningkatkan harga diri seseorang dan dengan harga diri yang tinggi dapat mempercepat proses penyembuhan individu yang menagalami ketergantungan narkoba.

Berkaitan dengan konsep diri dari data penelitian pecandu narkoba dominan berada pada kategori konsep diri yang positif, sejalan dengan hipotesis peneliti yang menyatakan ada hubungan yang positif antara konsep diri dengan penyesuaian diri, maka data penelitian pun menunjukkan bahwa subjek penelitian berada pada kategori penyesuaian diri yang baik di mana sebanyak 27 orang (90\%) masuk dalam kategori penyesuaian diri yang baik, sebanyak 1 orang $(3,33 \%)$ masuk dalam kategori penyesuaian yang buruk. Hal ini dapat diartikan bahwa bahwa penyesuaian diri data penelitian berada pada kategori penyesuaian diri yang baik (90\%.).

Dari seluruh data penelitian tersebut dapat dilihat bahwa konsep diri dan penyesuaian diri pecandu narkoba yang sedang menjalani rehabilitasi cenderung mengarah ke positif atau baik. Hal ini didukung oleh Rogers mengatakan bahwa konsep diri positif berhubungan erat dengan kemampuan menyesuaikan diri dengan baik, pengetahuan luas, harga diri tinggi, tidak mudah menyerah, selalu ingin mencoba pengalaman baru yang dianggapnya berguna dan memiliki pola perilaku optimis. Sedangkan konsep diri yang negatif akan membuat individu merasa dirinya tidak diperlukan, tidak diterima, tidak kompeten, menganggap dirinya kurang mampu, takut menghadapi hal-hal yang baru dan kurang berani memenuhi tuntutan hidupnya serta sering bersikap defensif dan menyalahkan orang lain.

Sejalan dengan itu, pecandu narkoba juga memiliki penyesuaian diri yang baik selama menjalani rehabilitasi sesuai dengan karakteristik yang dikemukakan oleh Schneiders yaitu tidak menunjukkan adanya ketegangan emosional, tidak menunjukkan adanyamekanisme-mekanisme psikologis, tidak menunjukkan adanya frustasi pribadi, memiliki pertimbangan rasional dan pengarahan diri, mampu dalam belajar, menghargai pengalaman bersifat realistik dan objektif

Berdasarkan perhitungan koefisien determinasi $\left(r^{2}\right)$, sumbangan efektif variabel konsep diri terhadap penyesuaian diri pecandu narkoba sebesar $24,4 \%$ sedangkan $75,6 \%$ lainnya menunjukkan besarnya pengaruh keberadaan variabel lainnya yang mempengaruhi penyesuaian diri pecandu narkoba. Faktor lain tersebut menurut Schneider (1964) yang tidak diteliti oleh peneliti, seperti kondisi fisik, kepribadian, edukasi, agama atau budaya.

\section{KESIMPULAN}

Berdasarkan hasil analisa data yang diperoleh dalam penelitian ini, maka dapat disimpulkan bahwa hipotesa diterima yang berarti ada hubungan yang positif antara konsep diri dengan penyesuaian diri pada pecandu narkoba di Panti Rehabilitasi Sibolangit Center.

\section{SARAN}

\section{Saran Metodologis}

Bagi peneliti selanjutnya yang ingin melakukan penelitian lebih lanjut mengenai konsep diri dan penyesuaian diri pada pecandu 
narkoba yang sedang menjalani rehabilitasi, diharapkan dapat meneliti hal tersebut dengan melibatkan banyak responden di banyak tempat panti rehabilitasi.

\section{Saran Praktis}

1. Bagi subjek penelitian

Para pecandu narkoba diharapkan untuk mempertahankan dan lebih meningkatkan konsep diri selama proses rehabilitasi, sehingga pecandu dapat melakukan penyesuaian diri yang baik. Sebagaimana hasil penelitian ini bahwa konsep diri berkorelasi positif terhadap penyesuaian diri pada pecandu narkoba.

2. Bagi Pengurus Rehabilitasi

Diharapkan dapat mempertahankan mempertahankan program TC karena program TC ini melibatkan pecandu untuk berinteraksi dengan pecandu lainnya layaknya keluarga, saling mendukung sehingga dapat membantu pembentukan konsep diri yang positif bagi masing-masing pecandu narkoba. Kemudian diharapkan panti rehabilitasi mampu meningkatkan jangka waktu rehabilitasi, program TC karena idealnya program TC diberikan selama lima sampai tujuh tahun. Pihak panti rehabilitasi dapat memperpanjang program TC dengan melakukan pertemuan rutin kepada pecandu narkoba yang sudah keluar dari panti rehabilitasi.

3. Bagi Keluarga dan Masyarakat

Diharapkan bagi keluarga ataupun masyarakat agar tidak memberikan label ataupun stigma yang negatif bagi para pecandu narkoba, melainkan memberikan dukungan kepada mereka agar mereka memiliki kepercayaan diri dan motivasi untuk pulih dari ketergantungan narkoba.

\section{REFERENSI}

Azwar, S. (2013). Penyusunan Skala Psikologi. Edisi II. Yogyakarta: Pustaka Belajar.

Calhoun, J.F., \& Acocella, J.R. (penerjemah: Satmoko, R.S.). (1990). Psikologi
Tentang Penyesuaian dan Hubungan

Kemanusiaaan. Semarang: IKIP Semarang Press.

Habibullah. (2010). Hubungan antara Konsep

Diri dengan Penyesuaian Diri

Gelandangan dan Pengemis. Jurnal

Penelitian dan Pengembangan

Kesejahteraan Sosial, Vol 15, No.2

Mischel,W.,Shoda,Y.,\&Smith,R. E. (2004). Introduction to

Personality: Toward An Integration ( $7^{\text {th }}$ edition). Hoboken, NJ: John Wiley \& Sons.

Schneider, A.A. (1964). Personal Adjustment adn Mental Health. New York: Holt, Reinhart \& Winston Inc. 